\title{
A GIS-Based Multicriteria Analysis of Land Suitability for Groundnut Crop in Nghe An Province, Vietnam
}

\author{
Nguyen, D. L., ${ }^{2,3 *}$ Chou, T. Y., ${ }^{1}$ Chen, M. H., ${ }^{1}$ Hoang, T. V. ${ }^{1}$ and Tran, T. P. ${ }^{3}$ \\ ${ }^{1}$ Geographic Information Systems Research Center, Feng Chia University, Taichung 40724, Taiwan. \\ E-mail: jimmy@gis.tw, ivy@gis.tw,van@gis.tw \\ ${ }^{2}$ Ph.D. Program for Civil Engineering, Water Resources Engineering, and Infrastructure Planning, College of \\ Construction and Development, Feng Chia University, Taichung 40724, Taiwan, E-mail: st_loc@gis.tw \\ ${ }^{3}$ Faculty of Natural Resources and Environment, Vietnam National University of Agriculture, Trau Quy, Gia \\ Lam, Hanoi, Vietnam, E-mail: ttphuong@vnua.edu.vn \\ *Corresponding Author \\ DOI: https://doi.org/10.52939/ijg.v17i6.2071
}

\begin{abstract}
This study focuses on identifying the potential lands for growing groundnut in Dien Chau district of Nghe An province (Vietnam), where groundnut is one of the major crops and brings high income for farmers. Based on the ecological requirements of groundnut, six criteria, including Soil Type, Soil Texture, Soil Depth, Slope, Average Temperature, and Average Total Rainfall in the planting season, were used. The Analytic Hierarchy Process method, commonly used in agricultural land use planning, was utilized to determine each criterion's weights via experts' opinions. A pairwise comparison matrix was established to support this assessment process. The results revealed that Soil Texture showed the highest weight (0.31727) for groundnut farming, which was followed by Average Temperature (0.21131), Soil Type (0.17426), and Soil Depth (0.13982). Slope and Average Total Rainfall were the lowest weight factors, with 0.08122 and 0.07612 , respectively. The weighted sum overlay analysis was implemented by ArcGIS software to generate the spatial distribution of land suitability of groundnut. The land suitability map indicated that $6830.07 \mathrm{ha}(22.26 \%)$ of the studied area was highly suitable (S1), 10413.85 ha (33.95\%) was moderately suitable (S2), 4336.76 ha (14.14\%) was marginally suitable (S3), and 424.99 ha (1.39\%) was not suitable (N). The total area of constrained area, including Waterbody and Built-up Land, was 8671.39 ha, accounting for 28.27\% of the total area. Finally, the proposed land for groundnut cultivation was $12928.69 \mathrm{ha}$. The outcomes of this study may be regarded as a good reference for local government in agricultural land use planning.
\end{abstract}

\section{Introduction}

The optimal growth of each plant species mainly depends on soil features and climatic conditions. Analyzing the relationship between soil features and crop requirements is significant as the first step in planning future agricultural land use (TaghizadehMehrjardi et al., 2020, Yohannes and Soromessa, 2018). It enables extensive information about land performances to land users, land-use planners, and agricultural support services, making a critical decision for specific purposes to increase productivity (AbdelRahman et al., 2016). Numerous crop management programs carried out land suitability assessment (LSA) to locate potential areas for the cultivation of various crops, such as rice (Özkan et al., 2019), maize (Habibie et al., 2021), potato (Iliquín Trigoso et al., 2020), rubber (Ali et al., 2018), and coffee (Salas López et al., 2020). These studies conclude that LSA considered the importance of land suitability assessment a pivotal step in selecting potential cultivated plants and areas. Therefore, soil characterization and land evaluation for various land use play a crucial role in proposing strategies for achieving food security and environmental sustainability (Esu, 2004).

Groundnut is one of the significant industrial crops to produce edible oil and daily food (Pasupuleti et al., 2013). In recent years, groundnut is investigated as a crop to improve the income and livelihoods of local farmers in Dien Chau district, Vietnam. The policies in groundnut land expansion have been mentioned on strategies for future agricultural development of local government, but a detail of land suitability assessment is not involved. Hence, this study evaluated land performance for groundnut growth in Dien Chau district, Vietnam. 
FAO land suitability evaluation was commonly used worldwide to evaluate the soils (FAO, 1976). However, examining the contribution of ecological criteria on land performance was ignored in this approach. More recently, LSE methodologies have shifted from broad-based to a specific assessment. Elshiek et al., (2013) developed an automated system (as per FAO framework) that allows land evaluators to build expert systems for land evaluation (Elsheikh et al., 2013). However, a quantitative procedure by GIS-based multicriteria analysis (MCA), inclusive of all the factors influencing crop production, needs to be developed to evaluate soil series. In MCA, the relative importance of quantitative criteria is used to rank different alternatives. While weights often express the relative importance of criteria, the performance of sub-criteria is expressed by score. Subjective experts' opinions estimate weights through a pairwise comparison matrix (Ebrahimi et al., 2019) or objective calculation by the principal component analysis approach (Kosaki et al., 1989). In order to apply efficiently for spatial analysis, MCA is usually combined with Geographical Information System (GIS). A GIS-based multicriteria analysis includes stepwise procedures to analyze objectives influenced by spatially distributed factors according to chosen criteria.

In short, the purpose of this study was to (i) apply a GIS-based multicriteria to assess land suitability; (ii) explore some potential areas to cultivate groundnut crops. This study's outcomes might help local government release the right policy in using agricultural land.

\section{Materials and Methods}

\subsection{Study Area}

Dien Chau $\left(18^{\circ} 51^{\prime} 31^{\prime \prime} \mathrm{N}-19^{\circ} 11^{\prime} 05^{\prime \prime} \mathrm{N}\right.$ latitude and $105^{\circ} 30^{\prime} 13^{\prime \prime} \mathrm{E}-105^{\circ} 39^{\prime} 26^{\prime \prime}$ E longitude) is a coastal district of Nghe An province with an area of 306.77 $\mathrm{km} 2$ (Figure 1). The study area is located in a monsoon tropical climate region, but a combined consequence of the Truong Son mountainous in West and sea in East has created considerable differences from weather conditions between dry and rainy seasons. The average annual temperature fluctuates between $23^{\circ} \mathrm{C}-24^{\circ} \mathrm{C}$. The highest temperature can be over $40^{\circ} \mathrm{C}$ in June or July. The average annual rainfall is about $1200 \mathrm{~mm}-2000$ $\mathrm{mm}$. The rainy season lasts from May to October. The topography of Dien Chau is divided into two forms, including hilly and coastal plains. The hilly terrains are mainly distributed in the northwestern and the south of the district. Their average elevation is from $100 \mathrm{~m}$ to $3000 \mathrm{~m}$ with a slope less than $15^{\circ}$. The remaining part is a flat sizeable coastal plain with an elevation from $0.5 \mathrm{~m}$ to $3.5 \mathrm{~m}$ and a slope less than $3^{\circ}$. The annual industrial crops in Dien Chau district include groundnut, soya-bean, tobacco, and sugar cane.

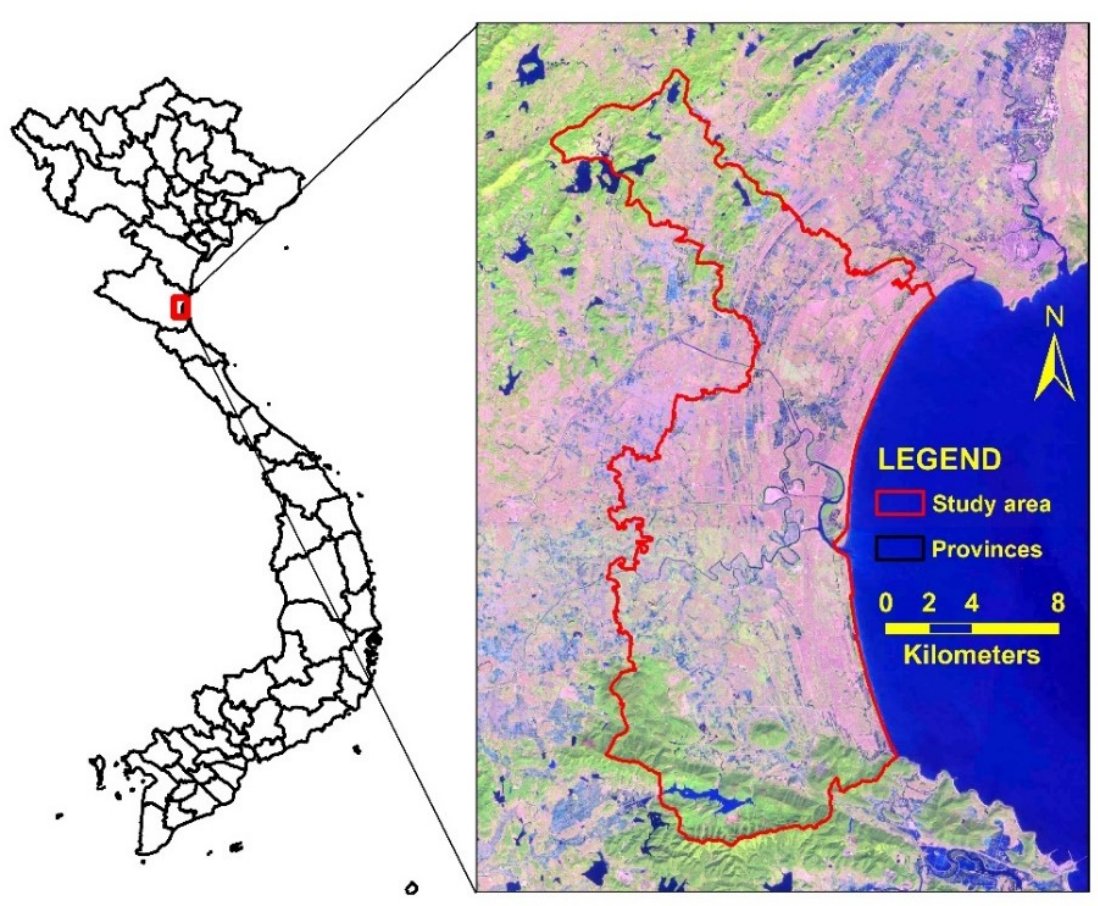

Figure 1: The location of study area 
In 2019, the planted area of groundnut is the biggest, with 3278 ha, which was followed by the number of sugar-cane (32 ha) and tobacco (6 ha). According to the Nghe An statistical yearbooks 2019, there was a slight increase in the planted groundnut area from 3061 ha to 3278 ha (NASO, 2020). Meanwhile, tobacco and sugar cane planted areas decreased marginally, especially soya-bean was not planted in 2019. Therefore, land suitability assessment for planting groundnut is significant in the agricultural production of this district.

\subsection{Criteria Used}

Determining ecological criteria for crop cultivation is essential in land suitability analysis due to their dependence on each physical factor (e.g., climate, topography, or soil). In more detail, these factors typically include temperature, rainfall, humidity, elevation, slope, aspect, soil texture, soil type, soil depth, soil drainage, organic matter, and $\mathrm{pH}$. Criteria were chosen based on crop type, a particular characteristic of the study area, technical regulation of each country, and data availability. For example, in order to determine the suitable site to grow rice in Turkey, Özkan et al., (2019) utilized nine characteristics of soil, including soil texture, soil drainage, $\mathrm{pH}, \mathrm{EC}, \mathrm{CaCO} 3, \mathrm{TN}, \mathrm{AvP}, \mathrm{AvK}$, and AvZn (Özkan et al., 2019). While Kihoro et al., (2013) used six factors, including topography, humidity, temperature, $\mathrm{pH}$, soil texture, and soil drainage, to assess suitable land levels to cultivate rice in Kenya (Kihoro et al., 2013). For groundnut cultivation, Gayathri (2018) utilized five criteria of the slope, soil texture, soil depth, drainage density, and mean annual rainfall to determine suitable lands in India (Gayathri, 2018). Suhairi et al., (2018) used rainfall, temperature, soil texture, soil depth, $\mathrm{pH}$, and elevation to evaluate land suitability to plant groundnut for Malaysia (Suhairi et al., 2018). This study used six criteria based on the Vietnamese technical regulation on "Agricultural production land evaluation instruction for land use planning at district level" (MARD, 2010) and experts' opinions. These criteria were Soil Type, Soil Texture, Soil Depth, Slope, Average Temperature in the planting season, and Average Total Rainfall in the planting season. Their sub-criteria were classified into four levels of suitability: high (S1), moderate (S2), marginal (S3), and not suitable (N), with corresponding scores from 4 to 1 .

\subsection{Data Used}

Meteorological data (i.e., rainfall and temperature) from 2015 to 2019, provided by the Vietnam
Institute of Meteorology Hydrology and Climate Change, was used to characterize climatic conditions. Soil Type, Soil Texture, and Soil Depth were extracted from the soil map at scale of 100,000 of Nghe An province. These data contained physical properties of soil in the study area and was obtained from the Soils and Fertilizers Research Institute. The slope information was generated from $10 \mathrm{~m}$ resolution of Dien Chau's DEM provided by the Center of Surveying and Mapping Data (Ministry of Natural Resources and Environment). Constrained areas, including Built-up land and Waterbody where groundnut can be not planted, were derived from the land use map of Dien Chau district. To validate the accuracy of the land suitability map, the location of 28 groundnut fields was collected using handheld GPS Garmin 72H in early October 2021.

\subsection{GIS-Based Multiple Criteria Analysis for Land Suitability Assessment}

Numerous methods were developed to assess the land potential for agricultural land. The FAO framework (FAO, 1976) for land suitability evaluation was considered standard and used for LSA projects (Fekadu and Negese, 2020 and Yohannes and Soromessa, 2018). This framework does not consider the different impact of ecological criteria on the land suitability assessment process, whereas each criterion has its contribution. For calculating the weight of criteria, the analytical hierarchy process (AHP) developed by Saaty (1980) was broadly used (Iliquín Trigoso et al., 2020 and Salas López et al., 2020). The importance of each criterion was estimated using an aggregation of experts' opinions. Besides, the LSA process becomes more straightforward with the support of spatial analysis tools of Geographic Information Systems (GIS). Many studies had effectively applied the integration of AHP and GIS to determine potential land for organic farming (Mishra et al., 2015), wheat and barley cultivation (Fekadu and Negese, 2020), or cassava (Purnamasari et al., 2019). Therefore, the application of GIS and AHP to determine land suitability for groundnut cultivation is feasible (Figure 2). The most important part of a land suitability evaluation model is to determine the weight of each criterion. Many ranking methods were used for this purpose, such as Analytical Hierarchy Process (Fekadu and Negese, 2020), Analytical Network Process (Seyedmohammadi et al., 2019), Weighted Linear Combination (Yin et al., 2020), and Ordered Weighted Average (Zabihi et al., 2019). 


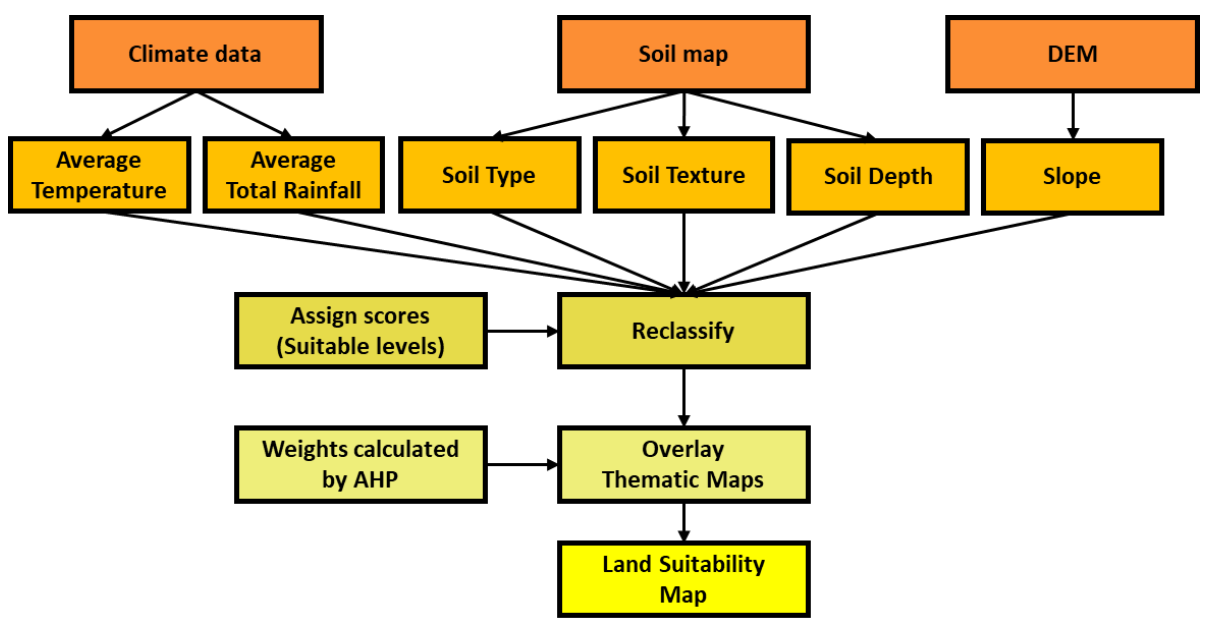

Figure 2: Flowchart of the methodology

Table 1: Saaty's nine points scale of pairwise comparison

\begin{tabular}{|c|c|c|c|c|c|c|c|c|}
\hline $1 / 9$ & $1 / 7$ & $1 / 5$ & $1 / 3$ & 1 & 3 & 5 & 7 & 9 \\
\hline Extreme & $\begin{array}{l}\text { Very } \\
\text { strong }\end{array}$ & Strong & Moderate & \multirow[t]{2}{*}{$\begin{array}{l}\text { Equally } \\
\text { important }\end{array}$} & Moderate & Strong & $\begin{array}{l}\text { Very } \\
\text { strong }\end{array}$ & Extreme \\
\hline \multicolumn{4}{|c|}{ Less important } & & \multicolumn{4}{|c|}{ More important } \\
\hline
\end{tabular}

Table 2: Consistency Ratio according to the number of criteria

\begin{tabular}{|c|c|c|c|c|c|c|c|c|c|c|}
\hline Number of criteria & $\mathbf{1}$ & $\mathbf{2}$ & $\mathbf{3}$ & $\mathbf{4}$ & $\mathbf{5}$ & $\mathbf{6}$ & $\mathbf{7}$ & $\mathbf{8}$ & $\mathbf{9}$ & $\mathbf{1 0}$ \\
\hline RI & 0 & 0 & 0.58 & 0.90 & 1.12 & 1.24 & 1.32 & 1.41 & 1.45 & 1.49 \\
\hline
\end{tabular}

However, the AHP method has been the most widely applied agricultural land suitability analysis (Iliquín Trigoso et al., 2020). To calculate the weights of criteria, using Pairwise Comparison Matrix (Table 1), where the relative importance of criteria is evaluated from 1 to 9 (Saaty, 1980). Experts decide these values, academic researchers, or decision-makers in the study field. The geometric mean method implemented the group aggregation of experts' judgments using Equation 1:

$$
M=\sqrt[n]{\prod_{i=1}^{n} a_{i}}
$$

Equation 1

Because of the subjective evaluation of experts, their judgments might be inconsistent (Francisco et al., 2019). For identifying the level of the inconsistency of the judgments, the consistency ratio index (CR) will be estimated by the Equation 2:

$$
C R=\frac{C I}{R I}
$$

Equation 2
With: RI is a random index provided by Saaty (Table 2). And CI is the Consistency Index, which is computed as Equation 3:

$$
C I=\frac{\lambda_{\max }-n}{n-1}
$$

Equation 3

In which, $\lambda_{\max }$ is the prime eigenvalue in the comparison matrix. Then $\mathrm{n}$ is the number of alternatives. It is suggested that $\mathrm{CR}<0.1$. In case that $\mathrm{CR}>0.1$, the level of consistency is not reasonable.

\subsection{Thematic Maps Generation}

\subsubsection{Rainfall and temperature}

The growth, flowering, and fruiting of groundnut are significantly affected by climatic conditions, including temperature and rainfall (Kumar et al., 2012 and Reddy et al., 2003). In Dien Chau district, groundnut is planted from July and harvested at the end of October. Average Temperature and Average Total Rainfall data in these months in Dien Chau district were interpolated based on nine meteorology stations' data in adjacent districts (Nghe An province) in the period 2015-2019. 


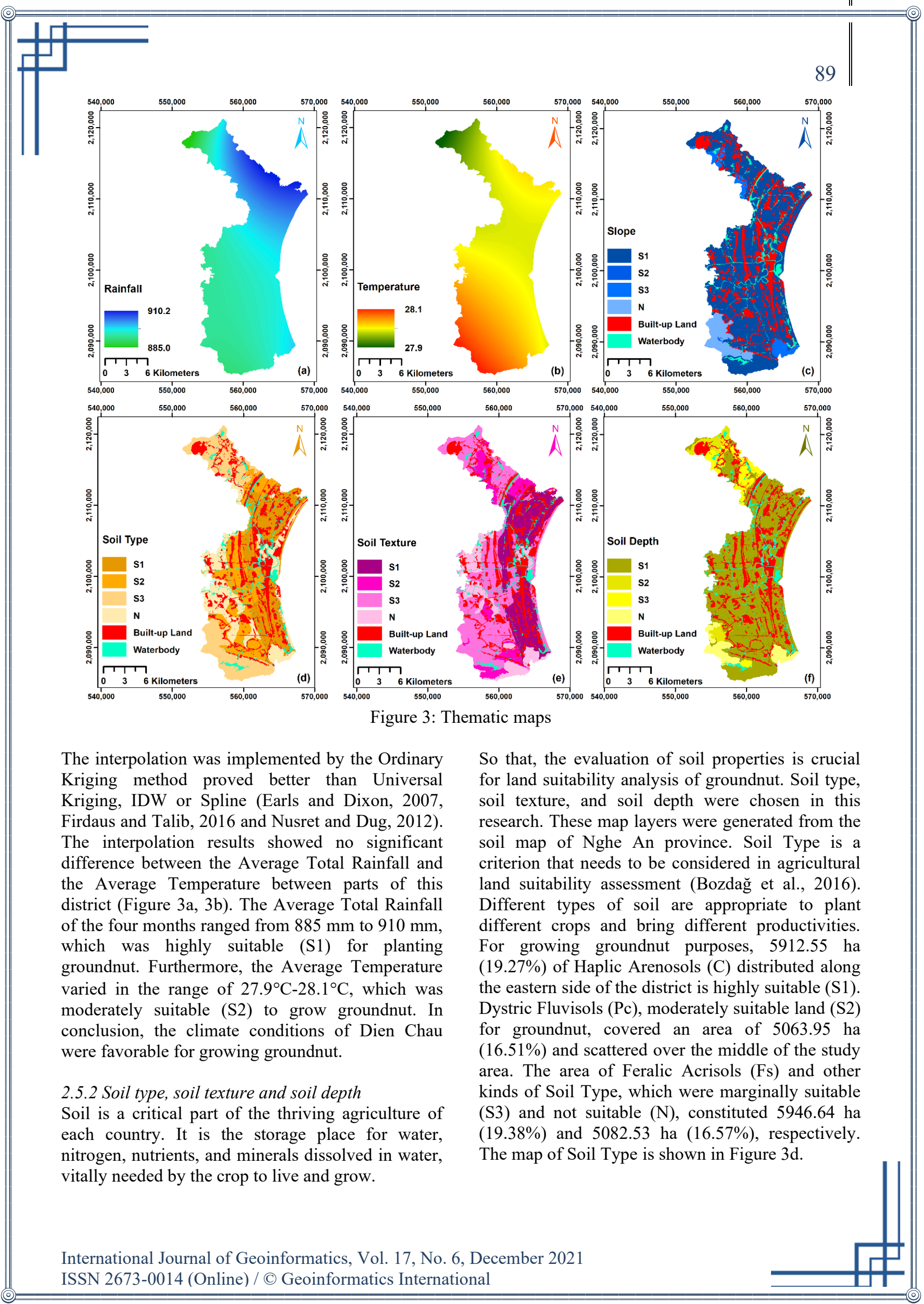


Table 3: Criteria, sub-criteria and their importance

\begin{tabular}{|c|c|c|c|c|c|c|}
\hline Criteria & Weights & Sub-criteria & $\begin{array}{c}\text { Suitable } \\
\text { levels }\end{array}$ & Score & $\begin{array}{c}\text { Area } \\
\text { (ha) }\end{array}$ & $\begin{array}{c}\text { Percentage } \\
(\%)\end{array}$ \\
\hline \multirow{4}{*}{ Soil Type } & \multirow{4}{*}{0.17426} & Haplic Arenosols (C) & S1 & 4 & 5912.55 & 19.27 \\
\hline & & Dystric Fluvisols (Pc) & S2 & 3 & 5063.95 & 16.51 \\
\hline & & Feralic Acrisols $(\mathrm{Fs})$ & S3 & 2 & 5946.64 & 19.38 \\
\hline & & Others & $\mathrm{N}$ & 1 & 5082.53 & 16.57 \\
\hline \multirow{4}{*}{ Soil Texture } & \multirow{4}{*}{0.31727} & Sandy (b) & S1 & 4 & 5846.24 & 19.06 \\
\hline & & Sandy Loam (c) & S2 & 3 & 2721.05 & 8.87 \\
\hline & & Sand (a), Silty loam(d) & S3 & 2 & 10172.70 & 33.16 \\
\hline & & Clay loam (e), Clay (g) & $\mathrm{N}$ & 1 & 3265.68 & 10.65 \\
\hline \multirow{4}{*}{ Soil Depth } & \multirow{4}{*}{0.13982} & $>70 \mathrm{~cm}$ & S1 & 4 & 17579.52 & 57.31 \\
\hline & & $50 \mathrm{~cm}-70 \mathrm{~cm}$ & S2 & 3 & 1034.26 & 3.37 \\
\hline & & $30 \mathrm{~cm}-50 \mathrm{~cm}$ & S3 & 2 & 1755.16 & 5.72 \\
\hline & & $<30 \mathrm{~cm}$ & $\mathrm{~N}$ & 1 & 1636.73 & 5.34 \\
\hline \multirow{4}{*}{ Slope } & \multirow{4}{*}{0.08122} & $0^{\circ}-3^{\circ}$ & S1 & 4 & 19036.36 & 62.05 \\
\hline & & $3^{\circ}-8^{\circ}$ & S2 & 3 & 31.95 & 0.10 \\
\hline & & $8^{\circ}-15^{\circ}$ & $\mathrm{S} 3$ & 2 & 1179.23 & 3.84 \\
\hline & & $>15^{\circ}$ & $\mathrm{N}$ & 1 & 1758.13 & 5.73 \\
\hline $\begin{array}{c}\text { Average } \\
\text { Temperature }\end{array}$ & 0.21131 & $27.9^{\circ} \mathrm{C}-28.1^{\circ} \mathrm{C}$ & S2 & 3 & 30677.06 & 100 \\
\hline $\begin{array}{l}\text { Average Total } \\
\text { Rainfall }\end{array}$ & 0.07612 & $885 \mathrm{~mm}-910 \mathrm{~mm}$ & S1 & 4 & 30677.06 & 100 \\
\hline
\end{tabular}

Soil Texture is defined as the ratio of sand, silt, and clay in soil content. It decides the aeration, waterreleasing capacity of the soil, and root penetrability. Thus, it has significant impacts on the growth of stems, leaves, flowers, and the number of pegs of groundnut (Zhao et al., 2015). In Dien Chau, Sand and Silty Loam (marginally suitable - S3) were dominant with 10172.70 ha $(33.16 \%)$, which was followed by the corresponding figures of Sandy (highly suitable - S1) with 5846.24 ha $(19.06 \%)$. Next were Clay loam and Clay (not suitable - N) with 3265.68 ha $(10.65 \%)$. Sandy Loam (moderately suitable - S2) had the lowest area, with only 2721 ha $(8.87 \%)$ (Table 3$)$. The map of Soil Texture is shown in Figure 3e.

Soil Depth is thick which crops' roots can penetrate, develop, and absorb the nutrient. Each crop requires a different depth of topsoil layers to grow well and produce a high yield (Sadras and Calviño, 2001). Deeper topsoil will supply more water and nutrients to crops than shallow topsoil. There was $57.31 \%$ of the study area, accounting for $17579.52 \mathrm{ha}$, deep over $70 \mathrm{~cm}$. It means over half of the study area had a highly suitable depth (S1) for planting groundnut. By contrast, suitable land, marginally suitable land, and unsuitable land with a depth ranging from 0 to $70 \mathrm{~cm}$, constituted about $15 \%$ of this district. Therefore, this district has favorable Soil Depth conditions for planting groundnut. The map of Soil Depth is shown in Figure 3f.

\subsubsection{Slope}

Another criterion that must be considered in the land evaluation process of agricultural land is Slope. It affects the depth of topsoil, irrigation, drainage, and especially the use of machines in the agricultural manufacturing process (AbdelRahman et al., 2016 and Özkan et al., 2020). The slope map showed that the terrain of Dien Chau district is relatively flat. The slope less than $3^{\circ}$, highly suitable (S1), dominated with $62.05 \%$ total area, accounting for 19036.36 ha. The slope greater than $3^{\circ}$ constitutes only about $10 \%$ total area. Hence, the topography condition of this district is very favorable to cultivate groundnut. The map of Slope is shown in Figure 3c.

\subsubsection{Constrained areas}

Built-up land and Waterbody cannot be cultivated. This land uses also will not be transformed to agricultural land by the current land policy. So they are considered restricted areas and excluded from the mapping of the suitable land assessment process. According to the map data, the area of Built-up land and Waterbody is 6719.51 ha and 1851.88 ha, accounting for $22.23 \%$ and $6.04 \%$ of the total area of Dien Chau district, sequentially. 


\subsection{Land Suitability Mapping}

Land suitability index (LSI) will be computed based on the weight of criteria and the score of suitable levels, as the Equation 4:

$$
L S I=\sum_{i=1}^{n} w_{i} \times s_{i}
$$

Equation 4

In which $\mathrm{n}$ is the number of criteria. The criteria weight is defined as $\mathrm{w}_{\mathrm{i}}$. Moreover, the score of subcriteria is represented as $\mathrm{s}_{\mathrm{i}}$. The weighted overlay technique can implement this work in ArcGIS software. The areas with a high land suitability index are more suitable for growing groundnut than those with a low land suitability index. The final land suitability map will be generated after the LSI is reclassified as the above proposal with four suitable levels: highly suitable, moderately suitable, marginally suitable, and unsuitable. The Equation calculates the difference between suitable levels 5:

$$
D=\frac{S_{\max }-S_{\min }}{N}
$$

Equation 5

Where $\mathrm{S}_{\max }$ is the highest score of suitable levels (4), $S_{\min }$ is the lowest score of suitable levels (1), and $\mathrm{N}$ is the number of ranking levels (4). In this study, $\mathrm{S}_{\max }=4, \mathrm{~S}_{\min }=1$ and $\mathrm{N}=4$. Hence, the difference between suitable levels $\mathrm{D}=(4-1) / 4=$ 0.75 and the scores of 4 suitable levels are 3.25-4, $2.5-3.25,1.75-2.5$, and 1-1.75, respectively.

\section{Results}

\subsection{Weight of Criteria}

Nine questionnaires were sent to experts of academic lecturers/researchers and local agricultural managers to evaluate the relative importance of six selected criteria. Their judgments were synthesized by the geometric mean method. Because it satisfies consistency requirements when aggregates the relative importance of pairwise comparisons (Barzilai, 1997). For estimating the weight of six selected criteria, the AHP method was implemented, and weights were calculated by normalizing the Pairwise Comparison Matrix (Table 4). Groundnut flowers above the ground and fruit under the ground require strict conditions of Soil Texture (Smartt, 1994). Furthermore, the growth and yield of groundnut also depend heavily on Soil Texture characteristics (Kanber et al., 1989). Therefore, it is easy to understand why Soil Texture was evaluated by the highest weight (0.31727). The second important criterion was Average Temperature with 0.21131 of weight. It can be explained by the strong dependence of the growing and fruiting of groundnut on temperature (Bolhuis and Groot, 1959). The weight of Soil Type was 0.17426 , which was followed by the corresponding figure of Soil Depth, with 0.13982. Slope and Average Total Rainfall were the two selected criteria having the lowest weight, with only 0.08122 and 0.07612 , respectively. Local agricultural managers explained this. They underestimated the influence of terrain and rainfall in the groundnut cultivation process in their district because most agricultural land is flat, and an irrigation canal system ensures irrigation. The consistency ratio of Pairwise Comparison judgments was $0.076995(<0.1)$, which indicated that these comparisons were consistent (Saaty, 1980). Furthermore, it showed that the relative weights were adequately selected.

The six chosen criteria can be gathered into three main groups: Soil (Soil Type, Soil Texture, Soil Depth), Climate (Average Temperature, Average Total Rainfall), and Topography (Slope). Furthermore, their total weights were 0.63135 , 0.28743 and 0.0812 , respectively. This result is a similar trend with previous results of agricultural land suitability in Turkey (Bozdağ et al., 2016), cropland suitability in Kenya (Kamau et al., 2015), significantly growing groundnut in Malaysia (Suhairi et al., 2018).

\subsection{Land Suitability Map}

The groundnut land suitability map showed the highly suitable areas, moderately suitable, marginally suitable, or not suitable to plant groundnut in Dien Chau district (Figure 4a). It was generated by the combination of thematic maps, criteria weights, and sub-criteria scores. The Weighted Overlay tool (in ArcGIS software) was effectively utilized for this purpose.

\begin{tabular}{|c|c|c|c|c|c|c|c|}
\hline Criteria & (1) & (2) & (3) & (4) & (5) & (6) & Weight \\
\hline Soil Type (1) & 1 & $1 / 2$ & 2 & 3 & $1 / 2$ & 2 & 0.17426 \\
\hline Soil Texture (2) & 2 & 1 & 2 & 3 & 4 & 3 & 0.31727 \\
\hline Soil Depth (3) & $1 / 2$ & $1 / 2$ & 1 & 3 & $1 / 2$ & 2 & 0.13982 \\
\hline Average Total Rainfall (4) & $1 / 3$ & $1 / 2$ & $1 / 3$ & 1 & $1 / 4$ & 1 & 0.07612 \\
\hline Average Temperature (5) & 2 & $1 / 4$ & 2 & 4 & 1 & 2 & 0.21131 \\
\hline Slope (6) & $1 / 2$ & $1 / 3$ & $1 / 2$ & 1 & $1 / 2$ & 1 & 0.08122 \\
\hline$\lambda \max =6.469$ & \multicolumn{2}{|c|}{$R I=1.24$} & \multicolumn{2}{|c|}{$\mathrm{CI}=0.094$} & \multicolumn{2}{|c|}{$C R=0.076$} & $\Sigma=1$ \\
\hline
\end{tabular}

Table 4: Pairwise comparison matrix 


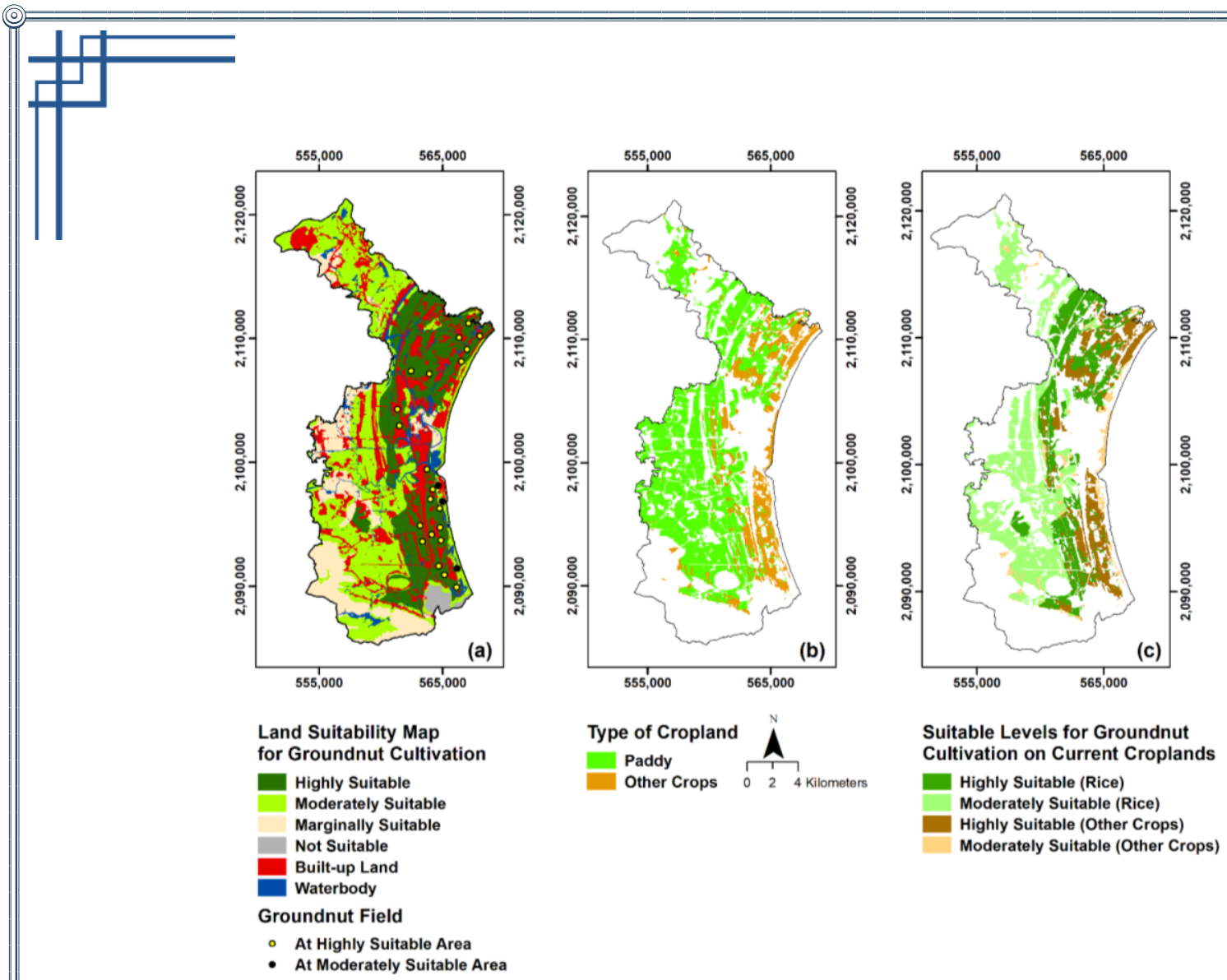

Figure 4: Land suitability maps

The calculation results revealed that the area of highly suitable land for growing groundnut was 6830.07 ha, making up $22.26 \%$. This area was about two times larger than the planted area of groundnut in 2019 (3,278 ha) and mainly concentrated in the eastern parts of the district with favorable conditions of physical properties of soil (Haplic Arenosols, Sandy, topsoil thickness $>70 \mathrm{~cm}$ ) and topography $\left(\right.$ Slope $<3^{\circ}$ ). These areas were ideal for groundnut cultivation and promised high yield and quality. The moderately suitable land covered the most prominent area, with $10,413.85$ ha, accounting for $33.95 \%$ of. It was over three times larger than the current actual planted area of groundnut and distributed in the western parts of the district. It was an integrated of Dystric Fluvisols, Sand, and Silty Loam, topsoil thickness $>70 \mathrm{~cm}$, and slope $<3^{\circ}$. The marginally suitable land was scattered in the western parts with 4336.76 ha, comprising $14.14 \%$. There was a small part with only 424.99 ha that was unsuitable for growing groundnut. It was located in the south of the district with unfavorable conditions of physical properties of soil and difficulty in using machinery because of a steep slope. According to the overlay analysis results between groundnut fields location and land suitability map, 25/28
(89.3\%) groundnut field was located in a highly suitable area, and $3 / 28(10.3 \%)$ groundnut field were located in a moderately suitable area (Figure $4 a)$. It means that farmers were right when selected location for groundnut cultivation and indicate a satisfactory fit between the land suitability map and currently agricultural practices.

\subsection{Proposed Land for Growing Groundnut}

The purpose of agricultural land planning is to indicate the best location for growing a specified crop. For achieving the highest production, the land for growing groundnut should be classified at a moderately suitable level or highly suitable level. Furthermore, planting groundnut on agricultural production land will be the most convenient because of the availability of irrigation and road systems. It will help farmers to be easy to implement intensive cultivation and transport their products (Mishra et al., 2015). In 2020, the total area of cropland was $14592.60 \mathrm{ha}$, including paddy (11158.14 ha) and other annual crops land (3434.46 ha). The other annual crops were predominantly groundnut and partly maize, sweet potato, mung bean, sesame, watermelon, vegetables. 
Table 5: Area of proposed land for groundnut cultivation

\begin{tabular}{|l|l|c|c|c|c|c|}
\cline { 2 - 6 } \multicolumn{1}{c|}{} & \multicolumn{2}{c|}{ Rice } & \multicolumn{2}{c|}{ Other Crops } & Total & Percent \\
\cline { 2 - 6 } \multicolumn{1}{c|}{} & Area (ha) & Percent (\%) & Area (ha) & Percent (\%) & Area (ha) & \begin{tabular}{c} 
(\%) \\
\hline \multicolumn{1}{c|}{}
\end{tabular} \\
\hline Highly Suitable & 3760.92 & 39.40 & 2645.34 & 78.20 & 6406.26 & 49.55 \\
\hline Moderately Suitable & 5784.93 & 60.60 & 737.50 & 21.80 & 6522.43 & 50.45 \\
\hline Total & 9545.85 & 100 & 3382.84 & 100 & 12928.69 & 100 \\
\hline
\end{tabular}

The crop's land map is shown in Figure $4 \mathrm{~b}$. The proposed land for growing groundnut is the intersection result of the two highest suitable classes of land suitability index map (highly suitable - S1 and moderately suitable - S2) and crops land map. The result revealed that there was 12928.69 ha, including 3382.84 ha of other annual crops land and 9545.85 ha of paddy land, to be proposed for groundnut cultivation (Figure 4c). The highly suitable land and moderately suitable land area were approximate, with 6406.26 ha $(49.55 \%)$ and 6522.43 ha $(50.45 \%)$, respectively. In order to reserve protective forest, some parts in the north and west of this district were not proposed to cultivate groundnut, although they were moderately suitable (Table 5).

The economic efficiency of groundnut production is 2-3 times higher than that of rice production (Sao and Dong, 2017). However, conversion of rice to groundnut on a large scale is infeasible and loses the balance of agricultural goods. For an effective transformation, the authority firstly should determine the low-efficiency rice land located on high lands and highly/moderately suitable for groundnut cultivation. Secondly, policies should be released to encourage farmers to transform from rice cultivation to groundnut cultivation, such as supporting the initial outlay of seed and fertilizer. Thirdly, supervising and technically consulting during the cultivation process to maximize productivity. Last but not least, finding the market for groundnut products both at home and abroad.

\section{Conclusion}

This research proposed GIS and AHP to evaluate land suitability in Dien Chau district for groundnut cultivation. Six criteria, namely Soil Texture, Soil Type, Soil Depth, Slope, Average Temperature, and Average Total Rainfall, were considered. AHP was used to estimate the weight of criteria based on experts' opinions of the importance of each criterion. Sub-criteria were classified into four classes, including highly suitable, moderately suitable, marginally suitable, and unsuitable, with corresponding scores of 4,3,2,1. The result showed that this district had great potential for planting groundnut, with 17243.92 ha of highly suitable land and moderately suitable land, accounting for $56.21 \%$ district's area. However, only 12928.69 ha of these lands where currently cultivate crops, were proposed to cultivate groundnut. The integration of GIS and AHP estimates the degree of influence of ecological factors and shows the location, area, and levels of land suitability for growing groundnut. This study is a good illustration of the usefulness of this method for multiple criteria decision-making. The study result can be utilized as a good reference for efficient use of land resources of local authorities.

\section{Acknowledgments}

We are grateful to Mr. Tran Hoai Nam (Land Registration Office, Department of Natural Resources and Environment) who was enthusiastically helped us to collect field data of groundnut fields in the days affected by the Covid pandemic.

\section{References}

AbdelRahman, M. A. E., Natarajan, A. and Hegde, R., 2016, Assessment of Land Suitability and Capability by Integrating Remote Sensing and GIS for Agriculture in Chamarajanagar District, Karnataka, India. The Egyptian Journal of Remote Sensing and Space Science, Vol. 19(1), 125-141. doi: https://doi.org/10.1016/j.ejrs.20-16.02.001.

Ali, S., Techato, K., Taweekun, J. and Gyawali, S., 2018. Assessment of Land Use Suitability for Natural Rubber Using GIS in the U-tapao River Basin, Thailand. Kasetsart Journal of Social Sciences. doi: 10.1016/j.kjss.2018.07.002.

Barzilai, J., 1997, Deriving Weights from Pairwise Comparison Matrices. Journal of the Operational Research Society, Vol. 48(12), 1226-1232. doi: $10.1057 /$ palgrave.jors. 2600474 .

Bolhuis, G. G. and Groot, W. D., 1959, Observations on the Efect of Varying Temperatures on the Flowering and Fruit Set in Three Varieties of Groundnut. The NJAS Wageningen Journal of Life Sciences, Vol. 7 (4), DOI: https://doi.org/10.18174/njas.v7i4.17669.

Bozdağ, A., Yavuz, F. and Günay, A. S., 2016, AHP and GIS Based Land Suitability Analysis for 
Cihanbeyli (Turkey) County. Environmental Earth Sciences, Vol. 75(9), 813. doi: 10.1007/s12665-016-5558-9.

Earls, J. and Dixon, B. M., 2007. Spatial Interpolation of Rainfall Data using ArcGIS: A Comparative Study. 27th Annual ESRI International User Conference. 1-9.

Ebrahimi, M., Nejadsoleymani, H. and Mansouri Daneshvar, M. R., 2019, Land Suitability Map and Ecological Carrying Capacity for the Recognition of Touristic Zones in the Kalat Region, Iran: A Multi-Criteria Analysis Based on AHP and GIS. Asia-Pacific Journal of Regional Science, Vol. 3(3), 697-718. doi: 10.1007/s41685019-00123-w.

Elsheikh, R., Mohamed Shariff, A. R. B., Amiri, F., Ahmad, N. B., Balasundram, S. K. and Soom, M. A. M., 2013, Agriculture Land Suitability Evaluator (ALSE): A Decision and Planning Support Tool for Tropical and Subtropical Crops. Computers and Electronics in Agriculture, Vol. 93, 98-110. doi: https://doi.org/10.1016/j.compag.2013.02.003.

Esu, I., 2004, Soil Characterization and Mapping for Food Security and Sustainable Environment in Nigeria. Proceedings of the 29th Annual Conference of the Soil Science Society of Nigeria, 20-24.

FAO, 1976, A Framework for Land Evaluation. Soils Bulletin. Food and Agriculture Organization of the United Nations., Vol. No. 32.

Fekadu, E. and Negese, A., 2020, GIS Assisted Suitability Analysis for Wheat and Barley Crops through AHP Approach at Yikalo Sub-Watershed, Ethiopia. Cogent Food \& Agriculture, Vol. 6(1), 1743623. doi: 10.1080/23311932.2020.1743623.

Firdaus, N. N. M. and Talib, S. A., 2016, Spatial Interpolation of Monthly Precipitation in Selangor, Malaysia - Comparison and Evaluation of Methods. Journal of Applied and Physical Sciences, Vol. 2(1), 1-9. doi: https://doi.org/10.20474/-japs2.1.1.

Francisco, H. R., Fabrício Corrêia, A. and Feiden, A., 2019, Classification of Areas Suitable for Fish Farming Using Geotechnology and Multi-Criteria Analysis. ISPRS International Journal of GeoInformation, Vol. 8(9). doi: 10.3390/ijgi8090394.

Gayathri, T. M. N., 2018, Crop-Land Suitability Analysis for Selected Crops in Vedaranyam Block, Tamil Nadu Using Remote Sensing And GIS. International Journal of Advance Research in Science and Engineering, Vol. 7(4), 407-420

Habibie, M. I., Noguchi, R., Shusuke, M. and Ahamed, T., 2021, Land Suitability Analysis for Maize Production in Indonesia using Satellite
Remote Sensing and GIS-based Multicriteria Decision Support System. GeoJournal, Vol. 86(2), 777-807. doi: 10.1007/s10708-019-100915.

Iliquín Trigoso, D., Salas López, R., Rojas Briceño, N. B., Silva López, J. O., Gómez Fernández, D., Oliva, M., Quiñones Huatangari, L., Terrones Murga, R. E., Barboza Castillo, E. and Barrena Gurbillón, M. Á., 2020, Land Suitability Analysis for Potato Crop in the Jucusbamba and Tincas Microwatersheds (Amazonas, NW Peru): AHP and RS-GIS Approach. Agronomy, Vol. 10(12). doi: 10.3390/agronomy 10121898 .

Kanber, R., Tekinel, O., Bastug, R., Onder, S. and Baytorun, N., 1989. Peanut Yield as Affected by Deficit Irrigation, Soil Texture, Sowing Date, and Irrigation Interval. Irrigation: Theory and Practice, 461-470.

Kihoro, J., Bosco, N. J. and Murage, H., 2013, Suitability Analysis for Rice Growing Sites using a Multicriteria Evaluation and GIS Approach in Great Mwea Region, Kenya. SpringerPlus, Vol. 2(1), doi: 10.1186/2193-1801-2-265.

Kosaki, T., Wasano, K. and Juo, A. S. R., 1989, Multivariate Statistical Analysis of YieldDetermining Factors. Soil Science and Plant Nutrition, Vol. 35(4), 597-607. doi: 10.1080/00380768.1989.10434795.

Kumar, U., Singh, P. and Boote, K. J., 2012, Chapter two - Effect of Climate Change Factors on Processes of Crop Growth and Development and Yield of Groundnut (Arachis hypogaea L.). In D. L. Sparks (Ed.), Advances in Agronomy, Vol. 116, 41-69. Academic Press.

MARD, 2010. TCVN 8409:2010: Agricultural Production Land Evaluation Instruction for Land Use Planning at District Level. Ministry of Agriculture and Rural Development (Vietnam).

Mishra, A. K., Deep, S. and Choudhary, A., 2015, Identification of Suitable Sites for Organic Farming using AHP and GIS. The Egyptian Journal of Remote Sensing and Space Science, Vol. 18(2), 181-193. doi: https://doi.org/10.1016/j.ejrs.2015.06.005.

NASO, 2020, Nghe An Statistical Yearbook 2019. Nghe An Statistical Office (NASO).

Nusret, D. and Dug, S., 2012. Applying the Inverse Distance Weighting and Kriging methods of the spatial interpolation on the mapping the annual precipitation in Bosnia and Herzegovina. International Congress on Environmental Modelling and Software. 1-8, https://scholarsarchive.byu.edu/cgi/viewcontent.cgi?article $=1878 \& \mathrm{c}$ ontext $=$ iemssconference. 
Özkan, B., Dengiz, O. and Demirağ Turan, İ., 2019, Site Suitability Assessment And Mapping for Rice Cultivation Using Multi-Criteria Decision Analysis Based on Fuzzy-AHP and TOPSIS Approaches Under Semihumid Ecological Condition in Delta Plain. Paddy and Water Environment, Vol. 17(4), 665-676. doi: 10.1007/s10333-019-00692-8.

Özkan, B., Dengiz, O. and Turan, İ. D., 2020, Site Suitability Analysis for Potential Agricultural Land with Spatial Fuzzy Multi-Criteria Decision Analysis in Regional Scale Under Semi-Arid Terrestrial Ecosystem. Scientific Reports, Vol. 10(1), 22074. doi: 10.1038/s41598-020-79105-4.

Pasupuleti, J., Nigam, S. N., Pandey, M. K., Nagesh, P. and Varshney, R., 2013, Groundnut Improvement: Use of Genetic and Genomic Tools. Frontiers in Plant Science, Vol. 4(23). doi: 10.3389/fpls.2013.00023.

Purnamasari, R. A., Ahamed, T. and Noguchi, R., 2019, Land Suitability Assessment for Cassava Production in Indonesia using GIS, Remote Sensing and Multi-Criteria Analysis. Asia-Pacific Journal of Regional Science, Vol. 3(1), 1-32. doi: 10.1007/s41685-018-0079-z.

Reddy, T. Y., Reddy, V. R. and Anbumozhi, V., 2003, Physiological Responses Of Groundnut (Arachis hypogea L.) to Drought Stress and its Amelioration: a Critical Review. Plant Growth Regulation, Vol. 41(1), 75-88. doi: 10.1023/A:1027353430164.

Saaty, T. L., 1980, The Analytic Hierarchy Process. McGraw Hill, New York, 1980. Reprinted by RWS Publications, 4922 Ellsworth Avenue, Pittsburgh, PA, 15213, 2000a.

Sadras, V. O. and Calviño, P. A., 2001, Quantification of Grain Yield Response to Soil Depth in Soybean, Maize, Sunflower, and Wheat. Agronomy Journal, Vol. 93(3), 577-583. doi:https://doi.org/10.2134/agronj2001.933577x.

Salas López, R., Gómez Fernández, D., Silva López, J. O., Rojas Briceño, N. B., Oliva, M., Terrones Murga, R. E., Iliquín Trigoso, D., Barboza Castillo, E. and Barrena Gurbillón, M. Á., 2020, Land Suitability for Coffee (Coffea arabica) Growing in Amazonas, Peru: Integrated Use of AHP, GIS and RS. ISPRS International Journal of Geo-Information, Vol. 9(11). doi: 10.3390/ijgi9110673.

Kamau, S. W., Kuria, D. and Gachari, M., 2015, Crop-land Suitability Analysis Using GIS and Remote Sensing in Nyandarua County, Kenya. Journal of Environment and Earth Science, Vol. 5(6), 121-131.
Sao, M. and Dong, L., 2017, Conversion of Rice Land Into Cropland in Dien Chau. Web portal of Dien Chau district. (Nghe An).

Seyedmohammadi, J., Sarmadian, F., Jafarzadeh, A. A. and McDowell, R. W., 2019, Integration of ANP and Fuzzy Set Techniques for Land Suitability Assessment Based on Remote Sensing and GIS for Irrigated Maize Cultivation. Archives of Agronomy and Soil Science, Vol. 65(8), 10631079. doi: 10.1080/03650340.2018.-1549363.

Smartt, J., 1994, The Groundnut Crop. Springer, Dordrecht.

Suhairi, T. A. S. T. M., Jahanshiri, E. and Nizar, N. M. M., 2018, Multicriteria Land Suitability Assessment for Growing Underutilised Crop, Bambara Groundnut in Peninsular Malaysia. IOP Conference Series: Earth and Environmental Science, Vol. 169, doi: 10.1088/-17551315/169/1/012044.

Taghizadeh-Mehrjardi, R., Nabiollahi, K., Rasoli, L., Kerry, R. and Scholten, T., 2020, Land Suitability Assessment and Agricultural Production Sustainability using Machine Learning Models. Agronomy, Vol. 10(4). doi: 10.3390/agronomy 10040573.

Yin, S., Li, J., Liang, J., Jia, K., Yang, Z. and Wang, Y., 2020, Optimization of the Weighted Linear Combination Method for Agricultural Land Suitability Evaluation Considering Current Land Use and Regional Differences. Sustainability, Vol. 12(23). doi: 10.3390/su122310134.

Yohannes, H. and Soromessa, T., 2018, Land Suitability Assessment for Major Crops by using GIS-based Multi-Criteria Approach in Andit Tid Watershed, Ethiopia. Cogent Food \& Agriculture, Vol. 4(1), doi: 10.1080/2331-1932.2018.1470481.

Zabihi, H., Alizadeh, M., Kibet Langat, P., Karami, M., Shahabi, H., Ahmad, A., Nor Said, M. and Lee, S., 2019, GIS Multi-Criteria Analysis by Ordered Weighted Averaging (OWA): Toward an Integrated Citrus Management Strategy. Sustainability, Vol. 11(4). doi: 10.3390/su11041009.

Zhao, C. X., Jia, L. H., Wang, Y. F., Wang, M. L. and McGiffen, M. E., 2015, Effects of Different Soil Texture on Peanut Growth and Development. Communications in Soil Science and Plant Analysis, Vol. 46(18), 2249-2257. doi: $10.1080 / 00103624.2015 .1059845$. 